\title{
Delays in the Diagnosis and Treatment of Pulmonary Tuberculosis
}

\author{
Pulmoner Tüberküloz Tanı ve Tedavisinde Gecikmeler
}

Gülbanu Horzum Ekinci, Osman Hacıömeroğlu, Adnan Yılmaz

\section{Abstract}

The primary goal of tuberculosis control programs is to minimize transmission within the community and reduce the incidence of tuberculosis by detecting and treating active tuberculosis cases as early as possible. Delays in the diagnosis and treatment of pulmonary tuberculosis can lead to a prolonged period of infection in the community. Delays are divided into patient delay, health care system delay, and total delay. The length of delays and possible reasons for delays in pulmonary tuberculosis patients are discussed in this paper.

Key words: Pulmonary tuberculosis, patient delay, doctor delay, total delay.

\section{Özet}

Tüberküloz kontrol programlarının birincil amacı toplum içinde hastalığın yayılmasını ve aktif tüberküloz hastalarını olabildiğince erken saptayarak ve tedavi ederek tüberküloz insidansını azaltmaktır. Tüberküloz tanı ve tedavisindeki gecikmeler toplumda enfeksiyonun bulaşma süresinin uzamasına neden olur. Gecikmeler hasta gecikmesi, sağlık sistemi gecikmesi ve toplam gecikme olarak gruplandırılır. Bu yazıda akciğer tüberkülozunda gecikmelerin boyutu ve olası nedenleri tartışılmıştır.

Anahtar Sözcükler: Akciğer tüberkülozu, hasta gecikmesi, doktor gecikmesi, total gecikme.
Although progress has been made in global tuberculosis control, the disease remains an important public health problem worldwide. Globally, tuberculosis is the second leading cause of death from communicable diseases (1). Almost 2.2 billion people, or one third of world's population, are infected with tuberculosis (2). The World Health
Organization (WHO) estimated that there were 8.6 million newly diagnosed tuberculosis cases and 1.3 million deaths from this disease in 2012 (3). The primary goals of tuberculosis control programs are to minimize transmission within the community and reduce the incidence of tuberculosis (4). The key elements in any tuberculosis control program

Clinic of Pulmonology, Süreyyapaşa Chest Diseases and Thoracic Surgery Training and Research Hospital, İstanbul, Turkey

Submitted (Başvuru tarihi): 27.08.2014 Accepted (Kabul tarihi): 27.10.2014

Correspondence (iletişim): Gülbanu Horzum Ekinci, Clinic of Pulmonology, Süreyyapaşa Chest Diseases and Thoracic Surgery Training and Research Hospital, İstanbul, Turkey

e-mail: gulbanuh@hotmail.com 
are early diagnosis of the cases and prompt initiation of effective treatment (5).

Tuberculosis infection primarily spreads in a community through patients with pulmonary tuberculosis. An untreated smear-positive patient can infect, on average, ten contacts annually and more than 20 during the natural history of the disease until death (6). Although it is widely believed that smear-negative cases are less infectious than smear-positive cases, it was reported that at least $17 \%$ of tuberculosis cases were the result of transmission from smear-negative tuberculosis cases (7). Delays in diagnosis and treatment result in a more extensive form of the disease, increased complications, higher costs, increased mortality, and a prolonged period of infectivity in the community (8). It was reported that delays in tuberculosis diagnosis were associated with greater transmission of infection to contacts (9). Delays in the diagnosis and treatment of tuberculosis patients have been commonly reported in both developing and developed countries (10-18). The current study aimed to discuss the length of delays and possible reasons for delays in pulmonary tuberculosis patients.

\section{DESCRIPTION AND CLASSIFICATION OF DELAYS}

Several time intervals from the onset of symptoms to treatment have been described in literature. These time intervals are as follows $(5,10,19)$ :

The patient's application interval: The patient's application interval was defined as the time interval between the onset of symptoms and the first doctor visit.

Health care system interval: The health care system interval was defined as the time from the first doctor visit to the initiation of treatment. Subgroups of health care system intervals are referral interval, diagnosis interval, treatment interval, and clinical interval. The referral interval was defined as the time from the first doctor visit to admission to hospital. The diagnosis interval was regarded as the time from admission to hospital to diagnosis of tuberculosis. The treatment interval was the time from diagnosis to initiation of treatment. The clinical interval was defined as the time from admission to hospital to initiation of treatment. The clinical interval is the sum of the diagnosis and treatment intervals.

Total interval: The total interval was defined as the time between the onset of symptoms and the time of treatment initiation. The total interval is the sum of the patient's application interval and health care system interval.
Delays are classified as patient delay, health care system, or doctor delay and total delay. Referral delay, diagnosis delay, treatment delay, and clinical delay are subcategories of doctor delay. Although the authors have described different duration intervals for the criteria of delays, the following operational criteria for delays have been usually used in most studies.

Patient delay: The patient's application intervals that exceeded 30 days were considered indicative of a patient delay in smear-negative and smear-positive patients (10,12,20-22).

Health care system delay or doctor delay: While health care system intervals that exceeded four days were considered indicative of a doctor delay in smear-positive patients $(10,20,22)$, a period of more than 15 days was indicative of a doctor delay in smear-negative patients $(12,22)$.

Referral delay: The referral intervals that exceeded two days were considered indicative of a referral delay in smear-negative and smear-positive patients (10,20-22).

Diagnosis delay: The diagnosis interval that exceed one day was considered indicative of a delayed diagnosis in smear-positive patients $(10,20)$.

Treatment delay: The treatment interval that exceed one day was defined as a delayed treatment $(10,20,21)$.

Clinical delay: While clinical intervals that exceeded two days were considered indicative of a clinic delay in smear-positive patients, a period of more than 13 days was indicative of a clinical delay in smear-negative patients $(10,12,20,22)$.

Total delay: While total intervals that exceeded 34 days were considered indicative of a total delay in smearpositive patients, a period of more than 45 days was indicative of a total delay in smear-negative patients $(10,12,20,22)$. Figure 1 shows the time intervals and delays.

\section{THE LENGTH OF DELAYS}

Delays in the diagnosis and treatment of tuberculosis patients have been commonly investigated by authors in previous studies. While most studies include smearpositive pulmonary tuberculosis patients, the number of studies evaluating delays in smear-negative and extrapulmonary tuberculosis patients is limited. Table 1 shows the results of several studies $(5,11,17,22-32)$.

Sub-categories of doctor delay were evaluated in some studies. One of these studies was conducted in Süreyyapaşa Center for Chest Diseases and Thoracic Surgery Training and Investigation Hospital in Istanbul, Turkey. 


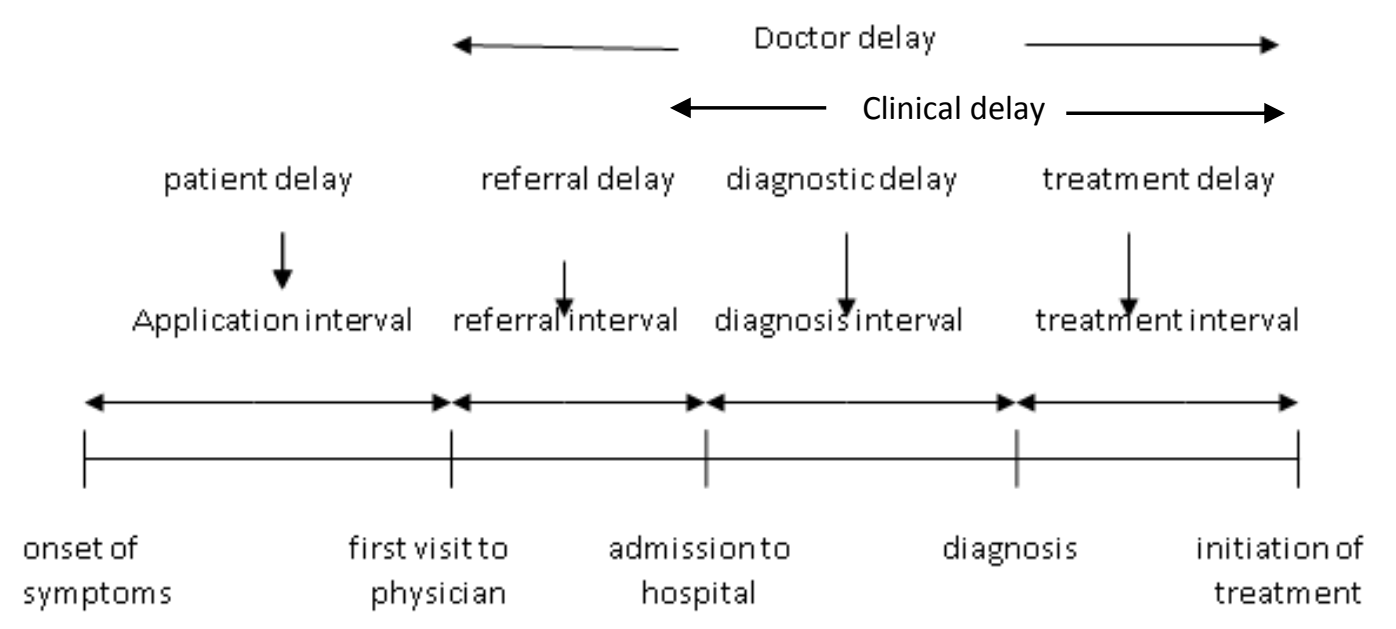

Figure 1: Time intervals and delays from onset of symptoms to initiation of treatment

Table 1: The median values associated with several intervals

\begin{tabular}{|c|c|c|c|c|c|}
\hline & & & \multicolumn{3}{|c|}{ Interval } \\
\hline Reference & Country & $\begin{array}{c}\text { Study } \\
\text { population }\end{array}$ & Application & $\begin{array}{c}\text { Health care } \\
\text { system }\end{array}$ & Total \\
\hline 5 & Kenya & $\mathrm{SP}^{*}$ & 42 days & 2 days & 44 days \\
\hline 11 & Tanzania & SP & 120 days & 15 days & 136 days \\
\hline \multirow[t]{2}{*}{17} & Norway & SP & 28 days & 14 days & 45 days \\
\hline & & $\mathrm{SN}^{*}$ & 14 days & 46 days & 60 days \\
\hline \multirow[t]{2}{*}{22} & Turkey & SP & 14 days & 16 days & 48 days \\
\hline & & SN & 10 days & 41 days & 61 days \\
\hline 23 & Thailand & SP & 4.4 weeks & 2.8 weeks & 9.4 weeks \\
\hline 24 & Argentina & SP & 31 days & 12.5 days & 62 days \\
\hline \multirow[t]{2}{*}{25} & USA & SP & 21 days & 6 days & 35 days \\
\hline & & SN & 27 days & 31 days & 79 days \\
\hline \multirow[t]{2}{*}{26} & Malaysia & SP & 2 weeks & 4 weeks & 13 weeks \\
\hline & & SN & 1.5 weeks & 8 weeks & 12 weeks \\
\hline 27 & India & SP & 20 days & 23 days & 60 days \\
\hline 28 & Ethiopia & SP & 30 days & 21 days & 80 days \\
\hline 29 & Hong Kong & $\mathrm{SP}+\mathrm{SN}$ & 20 days & 20 days & 49 days \\
\hline 30 & Vietnam & SP & 3 weeks & 1 weeks & 4 weeks \\
\hline \multirow[t]{3}{*}{31} & Nepal & SP & 60 days & 20 days & -- \\
\hline & & SN & 33 days & 15 days & -- \\
\hline & & EP* & 50 days & 30 days & -- \\
\hline 32 & Turkey & SP & 4.5 days & -- & 21 days \\
\hline
\end{tabular}

*SP: smear-positive pulmonary tuberculosis, SN: smear-negative pulmonary tuberculosis, EP: extra-pulmonary tuberculosis 
This study included 204 hospitalized patients with smear positive pulmonary tuberculosis. The median (mean) values were 17.5 (31.4) days for the application interval, 11 (22.1) days for the referral interval, 1.5 (3.3) days for the diagnosis interval, 1 (1.4) day for the treatment interval and 15 (26.7) days for the health care system interval (10). The other study was conducted at Heybeliada Center for Chest Disease and Thoracic Surgery Training and Investigation Hospital in Istanbul, Turkey. The study included 151 hospitalized patients with smear positive pulmonary tuberculosis. The median (mean) values were 30 (46.4) days for the application interval, 17 (28.9) days for the referral interval, 1 (2.4) day for the diagnosis interval, 1 (1) day for the treatment interval, and 19 (31) days for the health care system interval (20). A recent study from Süreyyapaşa Center for Chest Diseases and Thoracic Surgery Training and Investigation Hospital included 71 smear-positive and 65 smear-negative pulmonary tuberculosis patients. For smear-positive patients, the median patient, referral, clinical, health care system, and total intervals were $14,8,2,16$, and 48 days, respectively. For smear-negative patients, the median patient, referral, clinical, health care system, and total intervals were 10, $13,19,41$, and 61 days, respectively (22).

It was reported that the rates of the patients having delay among tuberculosis patients were high. Table 2 shows the results of several studies.

\section{FACTORS ASSOCIATED WITH THE LENGTH OF DELAYS}

It has been noted that many factors can affect the length of delays. Authors have investigated whether age, gender, level of education, economic status, marital status, occupation, distance to health center or physician, rural or urban residence, first symptom, presence of index case for tuberculosis, presence of comorbidity, smoking status, alcohol usage, sputum smear status, site of tuberculosis disease and the first physician affect the length of delays or not (4-6,8-14-16,18-20,24,27,30-36). A report from Turkey noted that age, gender, level of education and area of residence had no effect on the application interval. The authors found a shorter application interval in patients having an index case for tuberculosis and patients who had good economic status. The rate of patient delay was lower in patients with hemoptysis compare to patients with other first symptoms. The referral and diagnosis intervals were shorter in male patients in this study. Additionally, patients who were referred by a chest physician had a shorter referral interval than those referred by other physicians (10). Another Turkish study showed that age, gender, educational level, economic status, marital status, presence or absence of index case, co-morbidity, and the appearance of first symptoms had no effect on the application interval and the patient delay (20).

Table 2: The rate of the patients having delay with respect to delay criteria (\%)

\begin{tabular}{|c|c|c|c|c|c|c|c|c|c|}
\hline & & & \multicolumn{7}{|c|}{ Delay } \\
\hline Reference & Country & $\begin{array}{c}\text { Study } \\
\text { population }\end{array}$ & Patient & Referral & Diagnosis & Treatment & Clinic & Doctor & Total \\
\hline 10 & Turkey & $\mathrm{SP} *$ & 34.8 & 81.9 & 50.5 & 25 & $X$ & 87.2 & $X$ \\
\hline 19 & Turkey & SP & 28.4 & 61.1 & 69.4 & 25.4 & 73.7 & 88.8 & $x$ \\
\hline 20 & Turkey & SP & 49 & 90 & 49 & 7.9 & $X$ & 92.1 & $X$ \\
\hline 21 & Tanzania & SP & 35.1 & 89.4 & 52.9 & 34.3 & $x$ & 83.3 & $x$ \\
\hline \multirow[t]{2}{*}{22} & Turkey & SP & 33.8 & 63.4 & $x$ & $x$ & 40.8 & 77.5 & 62 \\
\hline & & SN* & 24.6 & 73.8 & $x$ & $x$ & 60 & 81.5 & 66.1 \\
\hline 26 & Malaysia & $\mathrm{SP}+\mathrm{SN}$ & 20 & $X$ & $X$ & $X$ & $X$ & $X$ & 83 \\
\hline 27 & India & SP & 29 & $x$ & $x$ & $x$ & $x$ & 60 & $x$ \\
\hline 28 & Ethiopia & $\mathrm{SP}$ & 48 & $x$ & $x$ & $x$ & $X$ & $x$ & 91 \\
\hline
\end{tabular}

*SP: Smear-positive patients, SN: Smear-negative patients. 
Wandwalo et al. (11) reported that the patient delay was significantly longer in rural areas and for patients with lower level of education. A study conducted in Mozambique indicated that farming and the coexistence of a chronic disease were associated with increased patient and health care system delays (14). It was reported that being aged 55-64 years was associated with longer patient delay and negative smear examination was associated with longer health care system delays (25). A study conducted in Vietnam noted that female gender, middle age, residence, and distance to health center were independent risk factors for delays (30). Smokers had a higher risk of patient delay and health care system delays (31). Ekinci et al. (22) found that smear-negative patients had longer health care system intervals and total intervals compared to smear-positive patients.

\section{REASONS FOR DELAYS}

Several possible reasons for patient delays and doctor delays have been described in previous reports. Characteristics of the patients such as gender, age, level of education, economic status, smear status, distance to a physician or health center, patients' area of residence, presence of index case for tuberculosis, and symptoms may affect the length of patient and doctor delays $(10,11,19$ $22,25,28)$. The most common potential reason for patient delay is the neglect of symptoms by the patient. A low index of suspicion for tuberculosis is an important reason for doctor delays $(10,19,20,22,37)$. An assessment of the response to antibiotic therapy is a common approach in patients with pulmonary symptoms and abnormal chest $x$-ray findings, which may result in doctor delays $(18,38)$. Table 3 summarizes possible reasons for patient delays and doctor delays.

In conclusion; delays from the onset of symptoms to treatment in pulmonary tuberculosis patients are a common problem. They are divided into patient delays, doctor or health care system delays and total delays. Referral delay, diagnosis delay, treatment delay, and clinical delay are subgroups of doctor delay. Prolonged delays increase the risk of infection transmission in the community. Therefore, delays should be reduced through various efforts to ensure effective tuberculosis control. Since a low index of suspicion of tuberculosis among physicians and the neglect of symptoms by the patients are common problems, physicians and the public should be educated about tuberculosis. Improvement in laboratory system delays and health care system delays are other important efforts to reduce delays.
Table 3: Possible reasons for patient delay and doctor delay

\begin{tabular}{|l|l|}
\hline Reasons for Patient Delay \\
\hline Distance to health center \\
Sociocultural factors \\
\hline Economic status \\
\hline Reasons for Doctor Delay \\
\hline A low index of suspicion for tuberculosis \\
\hline \begin{tabular}{l} 
Underutilized or delayed sputum examinations \\
Delays in chest x-ray examinations \\
Reasons associated with laboratory system \\
\hline Reasons associated with health care system \\
\hline Factors associated with patient
\end{tabular} \\
\hline
\end{tabular}

\section{CONFLICTS OF INTEREST}

None declared.

\section{AUTHOR CONTRIBUTIONS}

Concept - G.H.E., O.H., A.Y.; Planning and Design G.H.E., O.H., A.Y.; Supervision - G.H.E., O.H., A.Y.; Funding - G.H.E., O.H., A.Y.; Materials - G.H.E., O.H., A.Y.; Data Collection and/or Processing - G.H.E., O.H., A.Y.; Analysis and/or Interpretation - G.H.E., O.H., A.Y.; Literature Review - G.H.E., O.H., A.Y.; Writing - G.H.E., O.H., A.Y.; Critical Review - G.H.E., O.H., A.Y.

\section{YAZAR KATKILARI}

Fikir - G.H.E., O.H., A.Y.; Tasarım ve Dizayn - G.H.E., O.H., A.Y.; Denetleme - G.H.E., O.H., A.Y.; Kaynaklar G.H.E., O.H., A.Y.; Malzemeler - G.H.E., O.H., A.Y.; Veri Toplama ve/veya İsleme - G.H.E., O.H., A.Y.; Analiz ve/veya Yorum - G.H.E., O.H., A.Y.; Literatür Taraması G.H.E., O.H., A.Y.; Yazıyı Yazan - G.H.E., O.H., A.Y.; Eleştirel İnceleme - G.H.E., O.H., A.Y.

\section{REFERENCES}

1. World Health Organization. Global tuberculosis report 2012. Access date: 8 December 2014. Place of access

2. American Lung Association. Lung disease in diverse communities. 2010: 101-6.

3. World Health Organization. Global tuberculosis report 2013. WHO/HTM/TB/2013.15.

4. Maciel ELN, Golub JE, Peres RL, Hadad DJ, Favero JL, Molino LP, et al. Delay in diagnosis of pulmonary tuberculosis at a primary health care clinic in Vitoria, Brazil. Int J Tuberc Lung Dis 2010; 14:1403-10. 
5. Ayuo PO, Diero LO, Owingo-Ong'or WD, Mwangi AW. Causes of delay in diagnosis of pulmonary tuberculosis in patients attending a referral hospital in Western Kenya. East Afr Med J 2008; 85:263-8. [CrossRef]

6. Bassili A, Seita A, Baghdadi S, AlAbsi A, Abdilai I, Agboatwalla $M$, et al. Diagnostic and treatment delay in tuberculosis in 7 countries of the Eastern Mediterranean Region. Infect Dis Clin Prac 2008; 16:23-35. [CrossRef]

7. Behr MA, Warren SA, Salamon H, Hopewell PC, Ponce de Leon A, Daley CL, et al. Transmission of Mycobacterium tuberculosis from patients smear-negative for acidfast bacilli. Lancet 1999; 353:444-9. [CrossRef]

8. Lin HP, Deng CY, Chou P. Diagnosis and treatment delay among pulmonary tuberculosis patients identified using the Taiwan reporting enquiry system, 2002-2006. BMC Public Health 2009; 9:55. [CrossRef]

9. Golub JE, Bur S, Cronin WA, Gange S, Baruch N, Comstock GW, et al. Delayed tuberculosis diagnosis and tuberculosis transmission. Int J Tuberc Lung Dis 2006; 10:24-30.

10. Güneylioğlu D, Yilmaz A, Bilgin S, Bayram Ü, Akkaya E. Factors affecting delays in diagnosis and treatment of pulmonary tuberculosis in a tertiary care hospital in Istanbul, Turkey. Med Sci Monit 2004; 10:CR62-7

11. Wandwalo ER, Morkve O. Delay in tuberculosis casefinding and treatment in Mwanza, Tanzania. Int J Tuberc Lung Dis 2000; 4:133-8.

12. Demissie $M$, Lindtjorn $B$, Berhane $Y$. Patient and health service delay in the diagnosis of pulmonary tuberculosis in Ethiopia. BMC Public Health 2002; 2:23.

13. Storla DG, Yimer S, Bjune GA. A systemic review of delay in the diagnosis and treatment of tuberculosis. BMC Public Health 2008; 8:15. [CrossRef]

14. Saifodine A, Gudo PS, Sidat M, Black J. Patient and health system delay among patients with pulmonary tuberculosis in Beira City, Mozambique. BMC Public Health 2013; 13:559. [CrossRef]

15. Lacroix C, Martin P, Turcotte S, DeRoche S, Magluilo V, Lacroix $C$. The delay in diagnosis of tuberculosis in the Monteregie region of Quebec, Canada. Mcgill J Med $2008 ; 11: 124-31$.

16. Diez M, Bleda MJ, Alcaide J, Caloto T, Castells C, Cardenal Jl, et al. Determinants of patient delay among tuberculosis cases in Spain. Eur J Public Health 2004; 14:151-5.

17. Farah MG, Rygh JH, Steen TW, Selmer R, Heldal E, Bjune $G$. Patient and health care system delays in the start of tuberculosis treatment in Norway. BMC Infect Dis $2006 ; 6: 33$
18. Tattevin P, Che D, Fraisse P, Gatey C, Guichard C, Antonie $D$, et al. Factors associated with patient and health care system delay in the diagnosis of tuberculosis in France. Int J Tuberc Lung Dis 2012; 16:510-5. [CrossRef]

19. Yilmaz A, Boğa S, Sulu E, Durucu M, Yilmaz D, Baran A, et al. Delays in diagnosis and treatment of hospitalized patients with smear-positive pulmonary tuberculosis. Respir Med 2001; 95:802-5. [CrossRef]

20. Okur E, Yilmaz A, Saygi A, Selvi A, Süngün F, Öztürk E, et al. Patterns of delays in diagnosis amongst patients with smear- positive pulmonary tuberculosis at a teaching hospital in Turkey. Clin Microbiol Infect 2006; 12:90-2.

21. Mfinanga SG, Mutayoba BK, Kahwa A, Kimaro G, Mtandu R, Ngadaya $E$, et al. The magnitude and factors associated with delays in management of smear positive tuberculosis in Dar es Salaam, Tanzania. BMC Health Services Res 2008; 8:158. [CrossRef]

22. Ekinci GH, Karakaya E, Ongel EA, Haciomeroglu $O$, Yilmaz A. Patient and doctor delays in smear-negative and smear-positive pulmonary tuberculosis patients attending a referral hospital in Istanbul, Turkey. Scientific World Journal 2014; 2014:158186. [CrossRef]

23. Rojpibulstit $M$, Kanjanakiritamrong J, Chongsuvivatwong. Patient and health system delays in the diagnosis of tuberculosis in Southern Thailand after health care reform. Int J Tuberc Lung Dis 2006; 10:422-8.

24. Zerbini E, Chirico MC, Salvadores B, Amigot B, Estrada $S$ Algorry $G$. Delay in tuberculosis diagnosis and treatment in four provinces in Argentina. Int J Tuberc Lung Dis $2008 ; 12: 63-8$

25. Sherman LF, Fujiwara PI, Cook SV, Bazerman LB, Frieden TR. Patient and health care system delays in the diagnosis and treatment of tuberculosis. Int J Tuberc Lung Dis 1999 3:1088-95

26. Liam CK, Tang BG. Delay in the diagnosis and treatment of pulmonary tuberculosis in patients attending a university teaching hospital. Int J Tuberc Lung Dis 1997; $1: 326-32$

27. Rajeswari R, Chandrasekaran V, Suhadev M, Sivasubramaniam S, Sudha G, Renu G. Factors associated with patient and health system delays in the diagnosis of tuberculosis in South India. Int J Tuberc Lung Dis 2002; 6:789-95.

28. Yimer S, Bjune G, Alene G. Diagnostic and treatment delay among pulmonary tuberculosis patients in Ethiopia: a cross sectional study. BMC Infect Dis 2005; 5:112.

29. Leung EC, Leung CC, Tam CM. Delayed presentation and treatment of newly diagnosed pulmonary tuberculosis patients in Hong Kong. Hong Kong Med J 2007; $13: 221-7$ 
30. Huong NT, Vree M, Duong BD, Khanh VT, Loan VT, Co $N V$, et al. Delays in the diagnosis and treatment of tuberculosis patients in Vietnam: a cross-sectional study. BMC Public Health 2007; 7:1 10. [CrossRef]

31. Basnet R, Hinderaker SG, Enarson D, Malla P, Morkve O. Delay in the diagnosis of tuberculosis in Nepal. BMC Public Health 2009; 9:236. [CrossRef]

32. Okutan O, Kartaloglu Z, Cerrahoglu K, Ilvan A, Tozkoparan E, Aydilek R. Delay in the diagnosis of Turkish servicemen with pulmonary tuberculosis. Mil Med 2005; 170:211-3.

33. Lusigagni LS, Quaglio G, Atzori A, Nsuka J, Grainger R, Palma MC, et al. Factors associated with patient and health care system delay in diagnosis for tuberculosis in the province of Luanda, Angola. BMC Infect Dis 2013; 13:168. [CrossRef]

34. Schneider D, McNabb SJ, Safaryan M, Davidyants V, Niazyan L, Orbelyan S. Reasons for delay in seeking care for tuberculosis, republic of armenia, 2006-2007. Interdiscip Perspect Infect Dis 2010; 2010:412624. [CrossRef]

35. Whitehorn J, Ayles H, Godfrey-Faussett P. Extrapulmonary and smear-negative forms of tuberculosis are associated with treatment delay and hospitalisation. Int J Tuberc Lung Dis 2010; 14:741-4.

36. Ford CM, Bayer AM, Gilman RH, Onifade D, Acosta C, Cabrera $L$, et al. Factors associated with delayed tuberculosis test-seeking behavior in the Peruvian Amazon. Am J Top Med Hyg 2009; 81:1097-102. [CrossRef]

37. Odusanya OO, Babafemi JO. Patterns of delays amongst pulmonary tuberculosis patients in Lagos, Nigeria. BMC Public Health 2004; 4:18.

38. Golub JE, Bur S, Cronin WA, Gange S, Sterling TR, Oden B, et al. Impact of empiric antibiotics and chest radiograph on delays in the diagnosis of tuberculosis. Int $\mathrm{J}$ Tuberc Lung Dis 2005; 9:392-7. 